\title{
POTENTIAL EFFECT OF CAPTOPRIL, VALSARTAN ON NUCLEAR FACTOR KAPPA B AND LIPID PEROXIDATION IN HEPATIC ISCHEMIA- REPERFUSION INJURY IN RATS.
}

\author{
$\mathscr{B}_{y}$ \\ Sameh Ahmad Muhammad Abdel-ghany*, Hala Abdel-Malek Elashry ${ }^{\star \star *}$, \\ Maha Mohamad Ameen ${ }^{\star *}$, Karawan Mohamed Abd-El Rhman*** \\ and Abdel-Rahman Abdel-Fatah Yassin ${ }^{\star \star *}$ \\ From \\ ${ }^{*}$ Assistant lecturer of clinical pharmacology, Mansoura faculty of medicine \\ **Professor of pathology, Mansoura faculty of medicine \\ ${ }^{\star \star \star}$ Professor of clinical pharmacology, Mansoura faculty of medicine
}

\begin{abstract}
objectives: to evaluate hepatoprotective effect of captopril, valsartan in hepatic ischemia-reperfusion injury by assessing nuclear factor kappa $\mathrm{B}(\mathrm{NF}-\mathrm{\kappa} \mathrm{B})$ and lipid peroxidation.

Method: Twenty four rats were randomly divided into four groups, sham-operated group (control group), ischemia-reperfusion model (I/R group), IR with pretreated captopril 7 days before surgery(CAP group) and IR with pretreated valsartan 7days before surgery(VAL group) $3 \mathrm{~h}$ after induction of IR. Assay of serum liver enzymes alanine transaminase (ALT), aspartate transaminase
\end{abstract}

(AST), serum tumor necrosis factoralpha (TNF- $\alpha$ ) and interleukin - beta (IL-1 $\beta)$ as well as superoxide dismutase (SOD), malondialdehyde (MDA) in liver homogenates and liver NF- $\mathrm{KB}$ immunohistochemical analysis and hepatic pathology were evaluated in sacrificed rats after 3 hours of induction of IR.

Results: There was in IR group decrease of SOD and increase of MDA levels in liver homogenates 3 hours induction of IR. CAP and VAL pretreated groups showed significant increase of SOD and significant decrease of MDA compared to IR group after 3 hours of induction of MANSOURA MEDICAL JOURNAL 
IR. Serum liver enzymes AST and ALT were significantly increase in IR group compared to sham group. CAP and VAL pretreated groups showed significant decrease of AST and ALT compared to IR group. Serum cytokines TNF- $\alpha$ and IL-1 $\beta$ were significantly increase in IR group compared to sham group. CAP and VAL pretreated groups showed significant decrease of TNF- $\alpha$ and IL-I $\beta$ compared to IR group. NF-KB expression in liver cells (staining fraction) was significantly increase in IR group compared to sham group 3 hours after induction of IR. CAP and VAL pretreated groups showed significant decrease of NF-kB expression compared to IR group. CAP-IR \& VAL-IR groups caused significant decrease in combined score for liver morphology compared to IR group.

\section{INTRODUCTION}

$\mathrm{I} / \mathrm{R}$ injury is a common problem in organ transplantation(1). Hepatocellular harm caused by I/R happens in two phases(2). The first phase is caused by intense cell damage at 3 to 6 hours postreperfusion and incorporates the beginning of necrosis and apoptosis. The second phase of damage caused by reactions at 18 to 24 hours and is likewise connected with the increase of necrotic and apoptotic forms $(3)$. These procedures can result in chronic inflammation in the transplanted liver, a deterioration in liver function, and finally complete organ failure(3). Expanding proof proposes that the intense inflammatory reaction assumes a key part in I/ $\mathrm{R}$ injury, and NF-kB is a main transcriptional factor in the regulation of inflammatory factors $(4)$. The stimulation of NF-кB can up-regulate vascular endothelial cell adhesion molecules, for example, selectins, $\beta 2$ integrins and intercellular adhesion molecule (ICAM)-1 and increment the creation of neutrophil chemoattractants, including chemokines(5). Angiotensin-converting enzyme (ACE) inhibitors have verified in the decrease of ischemia/reperfusion damage after myocardial ischemia (6). Renin-angiotensin system (RAS) plays important roles in the advance of fibrosis and chronic inflammation in the liver $(7)$.

\section{MATERIALS AND METHODS \\ Chemicals and drugs \\ Captopril and valsartan were pur- chased as pure powders of the high-}


est research grade from SigmaAldrich Chemie GmbH (Germany).

Thiobarbituric acid (TBA) and reduced glutathione (GSH) were obtained from Fluka (Italy). Trichloroacetic acid (TCA) was obtained from Merk (USA).

Acetic acid, potassium dichromate, hydrogen peroxide, hydrochloric acid and ethanol were obtained from El-Nasr chemical (Egypt).

Serum laboratory and cytokine markers were assayed by using enzyme-linked immunosorbent assay (ELISA) kits.

Surgical instruments are from Harvard Apparatus Inc(USA). Sterile gauze, silk, Betadine solution, and sample collection tubes were purchased from local store.

Animals
Twenty four male adult male
sprague-dawely rats (6 in each
group) weighting $200-250$ gm body
weights each "(obtained from Medi-
cal Experimental Research Center
(MERC), Faculty of Medicine, Man-

soura University. All animals were housed at a tem-perature of 20$25^{\circ} \mathrm{C}$, a humidity of $65-69 \%$, and were subjected to a $12 \mathrm{~h}$ light/dark cycle with free access to standard chow food and tap water. The rats housed in cages (4 rats per cage). The experi-mental protocol was approved by the Ethics Committee of Mansoura faculty of medicine.

\section{Experimental Protocol}

The rats were randomly divided into two main groups:

i) sham-operated group, in which the blood vessels of the left and middle liver lobe were isolated, but without clamping, and after that the abdomen was closed without treatment and medication;

ii) IR group: further subdivided into a- I/R model (I/R group) ;

b- iii) Captopril pretreated group (CAP group), in which the rats were administered captopril (100 mg/kg/day oral seven days before surgery)(8);

c- Valsartan pretreated group (VAL group), in which the rats were administered valsartan (15 mg/kg/day oral seven days before surgery)(9). Each group included 6 rats.

MANSOURA MEDICAL JOURNAL 
172 POTENTIAL EFFECT OF CAPTOPRIL, VALSARTAN etc...

Hepatic I/R injury. Partial hepatic ischemia was induced as previously described (10). In short, the rats were anesthetized with intraperitoneal injection of $45 \mathrm{mg} / \mathrm{kg}$ ketamin $\mathrm{HCl}$ (Ketalar $^{\circledR}$, Pfizer) ${ }^{(11)}$ and $5 \mathrm{mg} / \mathrm{kg}$ xylazine (AnaSed $\AA$, Akorn) $)^{(11)} 1 \mathrm{~h}$ after the last medications. A midline laparotomy was made and a microvascular 'bulldog' clamp (Harvard Apparatus Inc.) used to clamp the portal vein branch and hepatic artery supplying the left lateral and median lobes for 90 minutes to interrupt the blood supply to the left lateral and median lobes of the liver. After 90 min of partial hepatic ischemia, the clip was removed to initiate reperfusion. The abdomen was closed with 4-0 silk sutures and the animals were allowed to awaken and were provided free access to food and water. Sham control rats underwent the same protocol without vascular occlusion. Rats were sacrificed three hours after reperfusion and samples of blood and ischemic lobes were collected for analyses."

\section{I- Biochemical analysis.}

a- Assay for Liver Enzymes (ALT,AST) in the serum were measured with ELISA colorimetric kits (BioVision, USA). Serum was collected and stored at $20^{\circ} \mathrm{C}$.

b- Assay for serum Cytokines TNF- alpha and IL-1?, were determined using rat TNF-alpha, IL-1 ? enzyme, linked immunosorbent assay (ELISA) kit (Abcam, MA,USA)

c- Oxidative stress assessment in liver homogenates to determine the activity of the antioxidant enzyme SOD and the level of MDA. Liver tissues were washed with cold PBS(Phosphate buffer saline), weighed and then homogenized in cold PBS (1 $\mathrm{ml}$ PBS per $100 \mathrm{mg}$ of tissue, $\mathrm{pH} \mathrm{7.4)}$ and centrifuged at $1500 \mathrm{xg}$ for $15 \mathrm{~min}$ at $4^{\circ} \mathrm{C}$. The clear supernatant fluid was collected to measure SOD activity and level of MDA. Samples were were assessed with a spectrophotometer at 532 and $450 \mathrm{~nm}$ respectively. The levels of SOD and MDA were in U/ $\mathrm{ml}$ and $\mathrm{uM} / \mathrm{g}$ respectively. The protein level in the liver homogenates was measured using colorimetric assay kits (Cayman, MI, USA).

\section{II- Histopathological Studies}

a) $H / E$ staining of liver sections 
Sameh Ahmad Muhammad Abdel-ghany et al ....

Liver specimens of the left lateral ysis of variance (ANOVA) followed lobe were sectioned, fixed in $10 \%$ by post-hoc tukey's was used. All (w/v) formalin buffer and embedded in paraffin. The sections were cut into $4 \mu \mathrm{m}$ sections and stained with hematoxylin/eosin for histological examination with a light microscope. The histological severity of I/R injury was graded using Suzuki's criteria (11).

b) Immunohistochemical( $\mathrm{IHC})$ analysis

Immunohistochemical staining for NF- $\mathrm{KB}$ protein was performed using the standard avidin-biotin complex staining procedure described previously on $4 \mu \mathrm{m}$ formalin-fixed, paraffin-embedded sections from a representative block of each sample(12). Computer-aided quantification of $\mathrm{IHC}$ positivity staining of NF-KB was performed $(13,14)$. The brown nuclear color of NF-кB staining was selected and the number of selected pixels was calculated from the histogram of colors, then the staining intensity of NF- $\kappa B$ was determined.

\section{Statistical analysis:}

The SPSS 22.0 statistical software package (SPSS Inc. Software, Chicago, Illinois, USA) For comparisons between groups, one-way analvalues are expressed as mean \pm standard deviation (SD) and $\mathrm{P}<0.05$ was considered statistically significant.

\section{RESULTS}

Effect of captopril and valsartan on oxidative stress markers (SOD, MDA)

Ischemia reperfusion group(IR) \& Captopril(CAP-IR) pretreated group $(6.21 \pm 0.87,7.93 \pm 0.92$ respectively) showed significant decrease in mean SOD level in liver tissue homogenate 3 hours after hepatic IR as compared to Sham group (9.51 \pm 0.95$) \quad$ while Valsartan pretreated (VAL-IR) group(8.25 \pm 0.85 ) showed non significance when compared to Sham group(table1). CAPIR \& VAL-IR groups showed significant increase in mean SOD level in liver tissue homogenate compared to IR group(table1). MDA level in in liver tissue homogenate 3 hours after hepatic IR, IR group( $18.78 \pm 2.11)$ showed significant increase compared to Sham group while CAP-IR \& VAL-IR group $(16.02 \pm 1.41, \quad 15.76 \pm 1.50)$ showed non-significance when compared to

MANSOURA MEDICAL JOURNAL 
Sham group (table1). CAP-IR \& increase in mean cytokines TNF- $\alpha$ \& VAL-IR groups caused significant IL-1 $\beta$ level in serum 3 hours after decrease in mean MDA level in liver tissue homogenate compared to IR group(table1).

Effect of captopril and valsartan on serum hepatic enzymes (ALT, AST)

IR, CAP-IR and VAL-IR groups $(470.3 \pm 53.6,332.1 \pm 61.3$ and $308.3 \pm 48.5$ respectively for $A L T)$ $(595.2 \pm 58.5,458.6 \pm 71.0$ and 439.8 \pm 67.0 respectively for AST) showed significant increase in mean ALT \& AST level in serum 3 hours after hepatic IR as compared to Sham group $(56.5 \pm 12.2$ for ALT)( $117.7 \pm$ 18.3 for AST) (table2). CAP-IR \& VAL-IR groups caused significant decrease in mean ALT \& AST level in serum 3 hours after hepatic IR compared to IR group(table2).

Effect of captopril and valsartan on serum cytokine levels (TNF- $\alpha$ and IL-1 $\beta$ )

IR , CAP-IR and VAL-IR groups $(174.1 \pm 29.5,104.1 \pm 26.4$ and $86.5 \pm 24.5$ respectively for TNF- $\alpha$ ) $(256.6 \pm 54.2,162.1 \pm 44.2$ and 146.2 \pm 42.6 for IL-1 $\beta$ ) showed significant hepatic IR as compared to Sham group (36.4 \pm 8.7 for TNF-?)( $74.8 \pm 17.6$ for IL-1 $\beta$ ) (table3). CAP-IR \& VAL-IR groups caused significant decrease in mean TNF- $\alpha$ \& IL-1 $\beta$ level in serum 3 hours after hepatic IR compared to IR group(table3).

Effect of captopril and valsartan on $N F-\kappa B$ expression in liver cells and liver morphology

IR, CAP-IR and VAL-IR groups $(29.30 \pm 4.63,20.12 \pm 5.15$ and 18.85 \pm 5.52 respectively) showed significant increase in mean of NF-kB expression in liver cells (staining fraction) 3 hours after hepatic IR as compared to Sham group $(7.23 \pm 1.81$ ) (table4). CAP-IR \& VALIR groups caused significant decrease in mean NF-KB expression in liver cells (staining fraction) 3 hours after hepatic IR compared to IR group(table4, fig.1). As regarded combined score for liver morphology, CAP-IR \& VAL-IR groups $(6.85 \pm 1.49$ and $5.77 \pm 1.29$ respectively)caused significant decrease 3 hours after hepatic IR compared to IR group (table4, fig.2). 
Table(1): Effect of captopril (100 mg/kg/day) and valsartan $(15 \mathrm{mg} / \mathrm{kg} /$ day) pretreatment for 7 days on oxidative stress markers (SOD, MDA) in liver tissue homogenate 3 hours after hepatic IR

\begin{tabular}{lcccc}
\hline & Sham & IR & CAP-IR & VAL-IR \\
\hline SOD(U/mg protein) & $9.51 \pm 0.95$ & $6.21 \pm 0.87^{\text {\#\# }}$ & $7.93 \pm 0.92^{* \#}$ & $8.25 \pm 0.85^{* *}$ \\
\hline MDA( $\mu$ M/g protein) & $14.22 \pm 1.92$ & $18.78 \pm 2.11^{\# \#}$ & $16.02 \pm 1.41^{*}$ & $15.76 \pm 1.50^{*}$ \\
\hline
\end{tabular}

Data represented as Mean $\pm \mathrm{SD}$ ( six rats per group)

$* \mathrm{P}<0.05 ; * * \mathrm{P}<0.01 ; * * * \mathrm{P}<0.001$ vs. non-treated group

$\# \mathrm{P}<0.05$; \#P $<0.01 ; \# \# \mathrm{P}<0.001$ vs. sham operated group

Test used: One way ANOVA followed by post-hoc tukey

Table(2): Effect of captopril (100 mg/kg/day) and valsartan $(15 \mathrm{mg} / \mathrm{kg} /$ day) pretreatment for 7 days on serum hepatic enzymes (ALT, AST) 3hours after hepatic IR

\begin{tabular}{|c|c|c|c|c|}
\hline & Sham & IR & CAP-IR & VAL-IR \\
\hline $\operatorname{ALT}(\mathrm{IU} / \mathrm{L})$ & $56.5 \pm 12.2$ & $470.3 \pm 53.6^{\ldots \#}$ & $332.1 \pm 61.3^{* * *}$ & $308.3 \pm 48.5^{5 * *}$ \\
\hline AST (IU/L) & $117.7 \pm 18.3$ & $595.2 \pm 58.5^{\# \#}$ & $458.6 \pm 71.0^{* *}$ & $439.8 \pm 67.0^{* * *}$ \\
\hline
\end{tabular}

Data represented as Mean $\pm \mathrm{SD}$ ( six rats per group)

${ }^{*} \mathrm{P}<0.05 ;{ }^{*} * \mathrm{P}<0.01 ;{ }^{* * *} \mathrm{P}<0.001$ vs. non-treated group

$\# \mathrm{P}<0.05 ; \# \mathrm{P}<0.01 ; \# \# \mathrm{P}<0.001$ vs. sham operated group

Test used: One way ANOVA followed by post-hoc tukey 
Table(3): Effect of captopril (100 mg/kg/day) and valsartan $(15 \mathrm{mg} / \mathrm{kg} /$ day $)$ pretreatment for 7 days on serum cytokine levels (TNF- $\alpha$ and IL-1 $\beta$ ) 3hours after hepatic IR

\begin{tabular}{|c|c|c|c|c|}
\hline & Sham & IR & CAP-IR & VAL-IR \\
\hline TNF- $\alpha$ (pg/ml) & $36.4 \pm 8.7$ & $174.1 \pm 29.5^{\# \#}$ & $104.1 \pm 26.4^{* * * \ldots \#}$ & $86.5 \pm 24.5^{* * * \ldots \#}$ \\
\hline $\mathrm{IL}-1 \beta(\mathrm{pg} / \mathrm{ml})$ & $74.8 \pm 17.6$ & $256.6 \pm 54.2^{\ldots \#}$ & $162.1 \pm 44.2^{* * \#}$ & $146.2 \pm 42.6^{* * * \#}$ \\
\hline
\end{tabular}

Data represented as Mean $\pm \mathrm{SD}$ ( six rats per group)

$* \mathrm{P}<0.05 ; * * \mathrm{P}<0.01 ; * * * \mathrm{P}<0.001$ vs. non-treated group

$\# \mathrm{P}<0.05 ; \# \mathrm{P}<0.01 ; \# \# \mathrm{P}<0.001$ vs. sham operated group

Test used: One way ANOVA followed by post-hoc tukey

Table(4): Effect of captopril (100 mg/kg/day) and valsartan (15 mg/kg/day) pretreatment for 7 days on $\mathrm{NF}-\mathrm{KB}$ expression in liver cells (measured by digital quantification of staining intensity of NFКB) and on liver morphology scoring using a combined Suzuki score 3-hours after hepatic IR.

\begin{tabular}{lcccc}
\hline & Sham & IR & CAP-IR & VAL-IR \\
\hline NF-kB(staining fraction) & $7.23 \pm 1.81$ & $29.30 \pm 4.63^{\text {\#\# }}$ & $20.12 \pm 5.15^{*} \ldots \#$ & $18.85 \pm 5.52^{* *}$ \#\# \\
\hline Combined score & - & $9.33 \pm 1.63$ & $6.85 \pm 1.49^{*}$ & $5.77 \pm 1.29^{* *}$ \\
\hline
\end{tabular}

Data represented as Mean $\pm \mathrm{SD}$ ( six rats per group)

$* \mathrm{P}<0.05 ;{ }^{*} \mathrm{P}<0.01 ; * * * \mathrm{P}<0.001$ vs. non-treated group

$\# \mathrm{P}<0.05 ; \# \mathrm{P}<0.01$; \#\#\#P<0.001 vs. sham operated group

Test used: One way ANOVA followed by post-hoc tukey

Vol. 44, No. 1 \& 2 Jan. \& April, 2015 

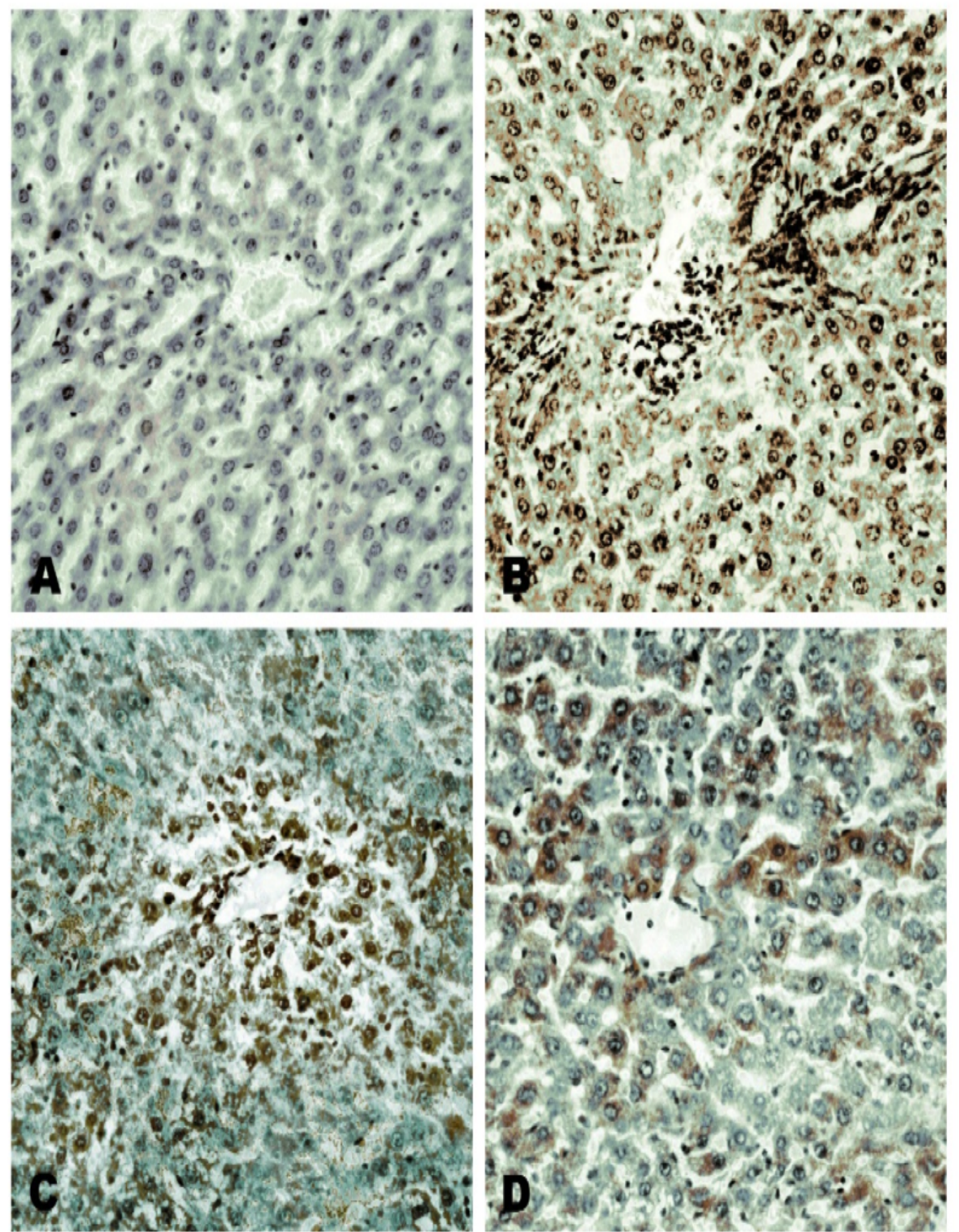

Fig.(1) Immunohistochemistry (IHC) of NF-kB in liver sections after $3 \mathrm{~h}$ of reperfusion. The staining intensity of sham rats is very weak and is mainly cytoplasmic with few nuclear staining (A). Staining intensity increased dramatically after $3 \mathrm{~h}$ of reperfusion (B). Pretreated rats with CAP (C), VAL (D) show significant reduction of staining intensity being maximally lowered with 

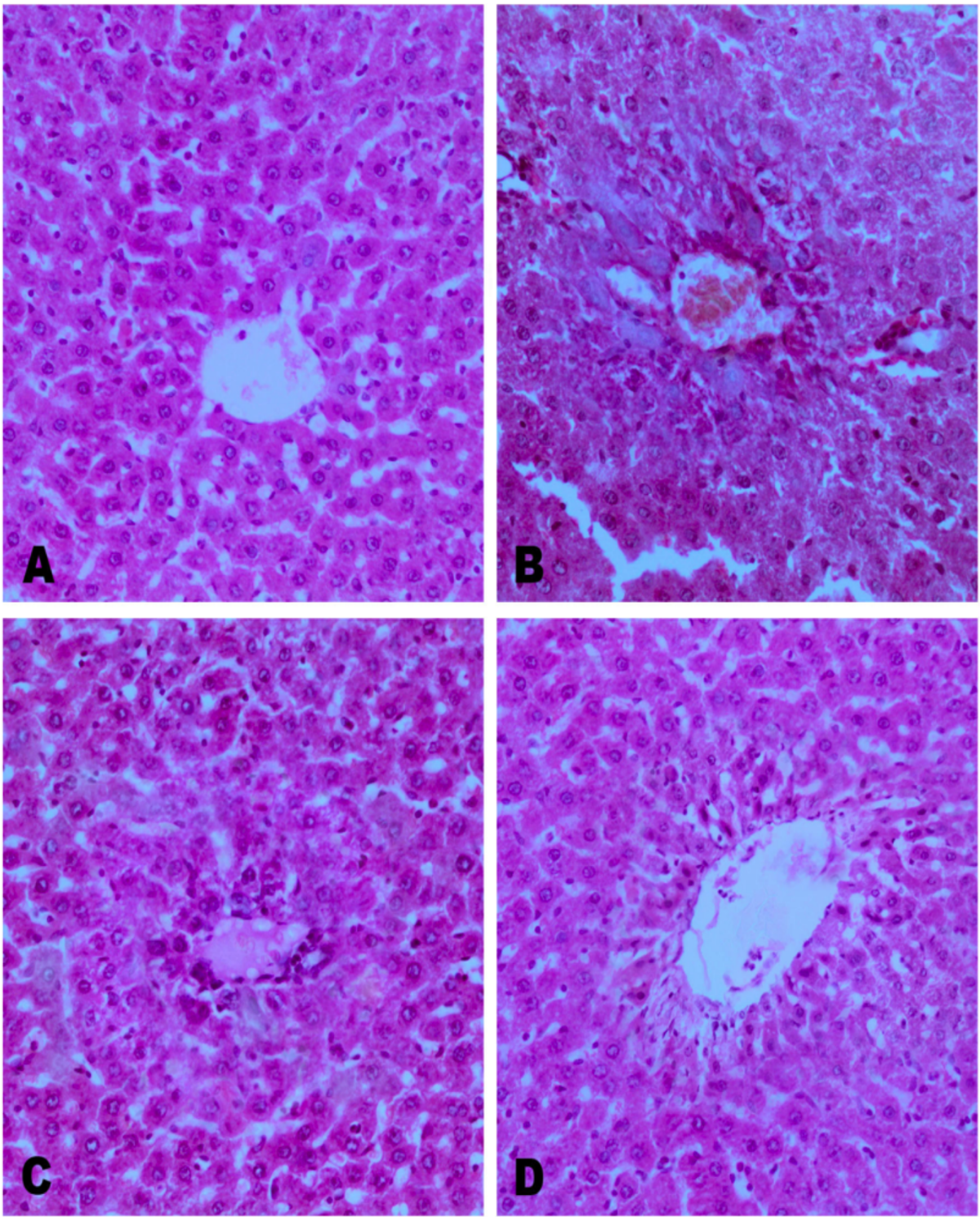

Fig.(2) H\&E staining of liver sections after $3 \mathrm{~h}$ of reperfusion. Sham operated rats had no marked abnormalities in morphology (A). Significant sinusoidal congestion, vaculization and necrosis are present in non-treated IR rats $(B)$. Rats pretreated with CAP (C) and VAL (D) show significant improvement of liver morphology and scoring criteria although few cell necrosis and inflammation are still shown (X100).

Vol. 44, No. 1 \& 2 Jan. \& April, 2015 
Sameh Ahmad Muhammad Abdel-ghany et al ....

\section{DISCUSSION}

Hepatic ischemia and reperfusion injury is a major problem during liver transplantation surgery. Captopril \& Valsartan are commonly used for treatment of hypertension in patients with impaired hepatic or renal functions, and additionally, they are of significant clinical importance in controlling hypertension in patients with liver transplantation $(15,16)$.

The involvement of renin angiotensin system(RAS) in cardiac and renal pathology following ischemia is well documented $(17,18)$. In addition to the systemic RAS, many other organs can express local functional RAS machineries that are regulated by modulators within the same organ. Research has revealed the presence of local RAS in the liver, its role in the pathogenesis of liver disease and fibrogenesis $(19,20)$.

Previous studies have shown that CAP is protective in various models of liver injury in rats $(21,22,23)$. Likewise, VAL has been used in different rat models of hepatic fibrosis $(24,25)$.

Results showed that induction of 90 minutes of partial hepatic ische- mia followed by 3 hours of reperfusion induced highly significant decline of the antioxidant enzyme SOD while elevated the lipid peroxide MDA in liver tissue. Bursts of reactive oxygen species (ROS) generated during early reperfusion have been also well documented since the late 1980's (26) as superoxide anion is known to be an early product of the incomplete reduction reaction in which oxygen is reduced to form water, and although superoxide anion has very short half-life in living systems, it is believed to be a major pathologic determinant in reperfusion injury (27).

In this study, the two examined drugs partially restored the oxidative stress markers with varying degree of efficiency being more significant with VAL. Previous studies have demonstrated that hepatic stellate cells(HSC) express the angiotensinII type 1 receptor(AT1) and that angiotensin II (Ang-II) exerted a marked concentration-dependent increase in intracellular calcium levels and cell proliferation (28). It was demonstrated that gene expression of both ACE and AT1 receptor were upregulated in areas of active hepat-

MANSOURA MEDICAL JOURNAL 
ic fibrogenesis after bile duct ligation (29).

Additionally, Ang-II was shown to stimulate gene expression of transform growth factor -beta(TGF- $\beta$ ) and fibronectin by activating AT1 receptors in Kupffer cells(KC)(30). In human samples of fibrotic livers, the expression of AT1 receptors was upregulated in HSC and bile duct epithelium (31).

De Giusti and co-workers had reviewed the relation between RAS and ROS generation in cardiac cells. The exact mechanism of this protection, however, is not clearly understood(32). CAP is a thiol-containing drug that has been reported to scavenge free radicals directly through its thiol moiety but the relative rate of this reaction has been suggested to be much slower than the rate of ROS generation during the oxidative process, even when used in pharmacological doses(33).

Moreover, similar antioxidant effects were observed with VAL, which, unlike CAP, does not possess thiol structure nor direct free radical scavenging properties. Therefore, it is unlikely that direct free radical scavenging effect is the main mechanism by which these drugs prevented free radical accumulation. A more comprehensive definition of antioxidants includes not only agents that directly react with free radicals, but also those that prevent the formation of these species at earlier stages $(33,34)$. In this framework, it is probably that prevention of tissue infiltration with inflammatory cells by CAP or VAL might contribute to the observed antioxidant effect.

Induction of 90 minutes of hepatic ischemia followed by 3 hours of reperfusion dramatically caused jacking up of serum liver enzymes several folds with a peak rise of serum ALT around ten folds after 3 hours of reperfusion and rise of AST but with relatively less magnitude which are all previously recognized responses to the acute ischemic liver injury (35).

The serum aminotransferases are sensitive indicators of hepatocyte injury(36). The most commonly measured are ALT and AST. Both ALT and AST are elevated in most liver diseases but striking elevation is seen in conditions involving hepato- 
cellular injury such as viral hepatitis, ischemic hepatitis, and drug toxicity. (37)

In the present study, the protective effect of CAP and VAL against hepatic IR evidenced by attenuation of the rise of serum liver enzymes at 3 hour time after reperfusion could be viewed as a result of attenuation of oxidative stress injury and prevention of cytosolic $\mathrm{Ca2}+$ overload in the hepatic cells. The liver contains local RAS components and liver cells express AT-1 receptors, furthermore, RAS is involved in the inflammatory response and mitochondrial ROS generation during ischemia and reperfusion (38). Accordingly, we can speculate that the inhibition of RAS by either CAP or VAL can, most probably, inhibit hepatocyte injury and prevent enzyme leakage.

Previous studies have reported that immediately following the initiation of reperfusion, various types of liver cell subpopulations produce proinflammatory cytokines including TNF- $\alpha$ and IL-1 $\beta(39,40)$.

In the present work, two principal cytokines involved in pathogenesis of IR injury, TNF- $\alpha$ and IL-1 $\beta$, were measured in serum of rats to assess the spectrum of effects of CAP and VAL on the immune modulation of hepatic IR. In present study, induction of 90 minutes of partial hepatic ischemia followed by 3 hours of reperfusion caused approximately 5 folds increase in serum TNF- $\alpha$ and 3 folds increase in serum IL-1 $\beta$ levels in non-treated rats.

Rats pretreated with CAP or VAL had lower levels of both TNF- $\alpha$ and IL-1 $\beta$ after 3 hours of reperfusion. The inhibitory effects of CAP on IL$1 \beta$ on lipopolysaccharide (LPS)stimulated production of proinflammatory cytokines have been additionally seen by Schindler and colleagues $(41)$. They detailed an inhibitory activity of CAP on the combination of TNF and IL-1 $\beta$, and this impact was apparently applied at a posttranscriptional level, in light of the fact that no impact on TNF- $\alpha$ or IL-1 $\beta$ mRNA could be watched(41). The effect of VAL on the cytokine production capacity has been investigated in another study (42). It had been informed that VAL has a potent inhibitory effect on LPS-stimulated production of the proinflammatory 
cytokines TNF- $\alpha$ and IL-1 $\alpha$.

$\mathrm{NF}-\kappa \mathrm{B}$ plays a vital role in regulating the production and activation of TNF- $\alpha$, IL-1 $\beta$, adhesion molecules, and other cytokines and chemokines. In non-activated cells, NF- $\kappa B$ is reserved in an inactive state in the cytoplasm by direct binding to NF- $\kappa B$ inhibitory protein $(\mathrm{I}-\kappa \mathrm{B})$. In response to inflammatory stimuli, including ROS and TNF- $\alpha, \mathrm{I}-\kappa \mathrm{B}$ proteins are phosphorylated and degraded unmasking the nuclear localization se-

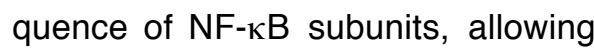
$\mathrm{NF}$-?B to translocate to the nucleus and bind specific promoter elements to induce gene transcription (43). NF$\kappa \mathrm{B}$, has been recognized to be fundamental in the cascade concerning with KC activation (44). The major effect of TNF- $\alpha$ is to induce liver cell injury through neutrophil activation, ROS production, and mitochondrial toxicity (45).

TNF- $\alpha$ also triggers expression of $N F-\kappa B$ and IL-1 $\beta$ which in turn upregulates the production of TNF- $\alpha$ in a positive feedback loop that can amplify the inflammatory response and extend the duration of inflammation (46).

Vol. 44, No. 1 \& 2 Jan. \& April, 2015
In this study, IHC staining of NF$\kappa \mathrm{B}$ was performed in formalin-fixed, paraffin-embedded liver sections via utilizing antibodies directed against the p65 (F6) component of the NF$\kappa \mathrm{B}$ complex (11). The staining intensity of NF- $\kappa B$ was analyzed and quantified via digital analysis of the acquired images using specialized image analysis software. In our study, the staining of NF- $\mathrm{KB}$ in sham rats was very scanty and was mainly cytoplasmic with few nuclear shadows. Three hours after reperfusion, there was significant increase in staining intensity of $N F-\kappa B$ in nontreated rats which became mainly nuclear indicating translocation of NF-kB from the cytoplasm to the nucleus. These finding coincide with data published in the literature where the activation of NF- $\kappa B$ in rats subjected to warm liver IR injury was shown to occur within 1-2 h after the initiation of reperfusion and started to decrease after $4 \mathrm{~h}$ (47).

Rats pretreated with CAP or VAL showed significantly smaller staining fractions of NF-kB after 3 hours of IR. Reports in the literature suggest that agents that decrease TNF- $\alpha$ levels and/or ROS generation also de- 
Sameh Ahmad Muhammad Abdel-ghany et al ....

crease NF- $\mathrm{KB}$ activation $(43,48,49)$.

The relation between RAS activation in the liver tissue and ROS generation during inflammation, and that mitochondrial ROS are released into the cytosol in response to RAS activation where they stimulate redox sensitive mitogen-activated protein kinases (MAPK). These MAPK trigger the increase in intracellular $\mathrm{Na}+$ which leads to increase in $\mathrm{Ca} 2+$ influx into the cell (32).

These results were further confirmed by histopathologic examination of liver sections.

The degree of inflammation, sinusoidal congestion, cytoplasmic vacuolization, and liver necrosis was semi-quantitatively examined according to a standardized scoring system described previously by Suzuki (11). It was observed that rats pretreated with CAP or VAL for 7 days before induction of hepatic IR showed significant improvement of liver morphology as evidenced by significant reduction of sinusoidal congestion, cell vacuolization/ necrosis and inflammatory cell infiltration at 3 hours after reperfusion.
The overall improvement in liver histology is the result of combined inhibition of RAS-induced ROS production, inhibition of cytokine release and prevention of NF-kB expression under ischemic condition.

In conclusion Pretreatment with Captopril and valsartan 7 days before IR resulted in improvement of oxidative stress, decrease in hepatic enzymes (AST,ALT) and cytokines (TNF $\alpha$ \&IL-I $\beta$ ). They cause decrease in expression of NF- $\mathrm{KB}$ as evidenced by decrease of staining intensity detected by digital Image analysis quantification. They cause also improvement in the histological picture of liver morphology. These results provides that pretreatment with captopril or valsartan could be used as a protective pharmacological strategy to prevent hepatic I/R injury with better results with valsartan than captopril."

\section{REFERENCES}

1- Strasberg SM, Howard TK, Molmenti EP, Hertl M. (1994) : Select ing the donor liver: risk factors for poor function after ortho-

MANSOURA MEDICAL JOURNAL 
topic liver transplantation.

Hepatology. Oct $1 ; 20$

(4):829-38.

2- Suzuki S. (1994) : Role of neutrophils during the first 24 hours after liver ischemia and reperfusion injury. Transplant Proc.; 26:3695700.

3- Schlossberg H, Zhang Y, Dudus L, Engelhardt JF. (1996) : Expression of $c$ fos and $\mathrm{c}$ jun during hepatocellular remodeling following ischemia/reperfusion in mouse liver. Hepatology. Jun 1;23(6):1546-55.

4- Liu SF, Ye X, Malik AB. (1999) : Inhibition of NF- $\kappa \mathrm{B}$ activation by pyrrolidine dithiocarbamate prevents in vivo expression of proinflammatory genes. Circulation. Sep 21; 100 (12):1330-7.

5- Livolsi A, Busuttil V, Imbert V, Abraham RT, Peyron JF. (2001) : Tyrosine phosphorylation dependent activation of NF $B$. The FEBS
Journal. Mar 1; 268

(5):1508-15.

6- Fan $H$, Sun B, Gu Q, LafondWalker A, Cao S, Becker LC. (2002) : Oxygen radicals trigger activation of NF- B and AP-1 and upregulation of ICAM-1 in reperfused canine heart. American Journal of PhysiologyHeart and Circulatory Physiology. May 1; 282 (5):H1778-86.

7- Jaeschke $H$, Hasegawa $T$. (2006) : Role of neutrophils in acute inflammatory liver injury. Liver International.Oct $1 ; 26(8): 912-9$.

8- Guo L, Richardson KS, Tucker LM, Doll MA, Hein DW, Arteel GE. (2004) : Role of the renin-angiotensin system in hepatic ischemia reperfusion injury in rats. Hepatology.; 40(3):583-9.

9- Qiang G, Zhang L, Yang $X$, Xuan Q, Shi L, Zhang $H$, Chen B, Li X, Zu M, Zhou D, Guo J, Yang H, (2012) : Du G Effect of valsartan on 
Sameh Ahmad Muhammad Abdel-ghany et al ....

the pathological progres-

sion of hepatic fibrosis in rats with type 2 diabetes.

Eur J Pharmacol.; 685 (1-

3):156-64.

10- Kerem M, Bedirli A, Pasaoglu

$H$, Ofluo_lu E, Yilmazer D, Salman B, Yilmaz TU. (2008) : Effect of adrenomedullin on hepatic damage in hepatic ischaemia/ reperfusion injury in rats. Liver Int; 28(7):972-81.

11- Li Y, Li T, Qi H, Yuan F. (2015) : Minocycline protects against hepatic ische$\mathrm{mia} /$ reperfusion injury in a rat model. Biomedical reports. Jan 1;3(1):19-24.

12- Li W, Tan D, Zenali MJ, Brown RE. (2010) : Constitutive activation of nuclear factor-kappa B (NF-kB) signaling pathway in fibrolamellar hepatocellular carcinoma. Int $\mathrm{J}$ Clin Exp Pathol.; 3(3): 238-243.

13- Dahab GM, Kheriza M, EIBeltagi HM, Fouda AM, and Sharaf EI-Din $O$ :
(2004) : Digital quantification of fibrosis in liver biopsy sections: description of a new method by Photoshop software. J Gastroenterol Hepatol.; 19: 78-85.

14- Rizzardi AE, Johnson AT, Vogel RI, Pambuccian SE, Henriksen J, Skubitz AP, Metzger GJ, and Schmechel SC (2012) : Quantitative comparison of immunohistochemical staining measured by digital image analysis versus pathologist visual scoring. Diagn Pathol.; 7: 42.

15- Eltzschig HK and Eckle T. (2011) : Ischemia and reperfusion-from mechanism to translation. Nat Med. 17 (11): 1391-401.

16- Najeed SA, Saghir S, Hein B, Neff G, Shaheen M, Ijaz H, Khan IA. (2011) : Management of hypertension in liver transplant patients. Int J Cardiol. 2011; 152 (1):4-6.

17- Skipworth JR, Szabadkai G, MANSOURA MEDICAL JOURNAL 
Olde Damink SW, Leung PS, Humphries SE, Montgomery HE. (2011) : Pancreatic renin-angiotensin systems in health and disease. Aliment Pharmacol Ther. 2011; 34(8):840-52.

18- Marshall RP. (2003) : The pulmonary renin-angiotensin system. Curr Pharm Des.; 9(9):715-22.

19- Grace JA, Herath CB, Mak KY, Burrell LM, Angus PW. (2012) : Update on new aspects of the reninangiotensin system in liver disease: clinical implications and new therapeutic options. Clin Sci (Lond). 2012; 123(4):225-39.

20- Bataller R, Sancho-Bru P, Gines $\mathrm{P}$, Lora JM, AlGarawi A, Sole M, Colmenero J, Nicolas JM, Jimenez W, Weich N. (2003a) : Activated human hepatic stellate cells express the renin-angiotensin system and synthesize angiotensin II. Gastroenterology.; 125 : 117-125.

Vol. 44, No. 1 \& 2 Jan. \& April, 2015
21- Guo L, Richardson KS, Tucker LM, Doll MA, Hein DW, Arteel GE. (2004) : Role of the renin-angiotensin system in hepatic ischemia reperfusion injury in rats. Hepatology.; 40(3):583-9.

22- Tuncer I, Ozbek H, Ugras S, Bayram I. (2003) : Antifibrogenic effects of captopril and candesartan cilexetil on the hepatic fibrosis development in rat. The effect of AT1-R blocker on the hepatic fibrosis. Exp Toxicol Pathol.; 55(23):159-66.

23- Jonsson JR, Clouston AD, Ando Y, Kelemen LI, Horn MJ, Adamson MD, Purdie DM, Powell EE. (2001) : Angiotensinconverting enzyme inhibition attenuates the progression of rat hepatic fibrosis. Gastroenterology.;

121 (1):148-55 .

24- Qiang G, Zhang L, Yang X, Xuan $Q$, Shi L, Zhang $H$, Chen B, Li X, Zu M, Zhou D, Guo J, Yang H, (2012) : 
Sameh Ahmad Muhammad Abdel-ghany et al ....

Du G Effect of valsartan on the pathological progression of hepatic fibrosis in rats with type 2 diabetes. Eur J Pharmacol. 2012; 685(1-3):156-64.

25- $X u$ W, Song $S$, Huang $Y$, Gong Z. ( 2006) : Effects of perindopril and valsartan on expression of transforming growth factor-betaSmads in experimental hepatic fibrosis in rats. J Gastroenterol Hepatol.; 21 (8):1250-6.

26- Garlick PB, Davies MJ, Hearse DJ, Slater TF. (1987) : Direct detection of free radicals in the reperfused rat heart using electron spin resonance spectroscopy. Circ Res.; 61 (5):757-60.

27- Jones DP. (2008) : Radicalfree biology of oxidative stress. Am J Physiol Cell Physiol.; 295(4):C849-68.

28- Bataller R, Gabele E, Schoonhoven R, Morris T, Lehnert M, Yang L. (2003b) :
Prolonged infusion of angiotensin II into normal rats induces stellate cell activation and proinflammatory events in liver. Am J Physiol Gastrointest Liver Physiol; 285:G642-G651.

29- Paizis G, Cooper ME, Schembri JM, Tikellis C, Burrell LM and Angus PW. (2002) : Up-regulation of components of the reninangiotensin system in the bile duct-ligated rat liver. Gastroenterology.; 123 : 1667-1676.

30- Leung PS, Suen PM, Ip SP, Yip CK, Chen G, Lai PB. (2003) : Expression and localization of AT1 receptors in hepatic Kupffer cells: its potential role in regulating a fibrogenic response. Regul Pept; 116:61- 69.

31- Schulte S, Oidtmann A, Kociok N, Demir M, Odenthal M, Drebber U, Dienes HP, Nierhoff D, Goeser T, Toex U, Steffen HM. (2009) : Hepatocyte expression of angiotensin II

MANSOURA MEDICAL JOURNAL 
type 1 receptor is downregulated in advanced human liver fibrosis. Liver Int 2009; 29:384-91

32- De Giusti VC, Caldiz CI, Ennis IL, Pérez NG, H. Cingolani $\mathrm{HE}$ and E. Aiello EA. (2013) : Mitochondrial reactive oxygen species (ROS) as signaling molecules of intracellular pathways triggered by the cardiac renin-angiotensin IIaldosterone system (RAAS). Front. Physiol.; doi.org/10.3389/

fphys.2013.00126

33- Aruoma OI, Akanmu D, Cecchini R, Halliwell B. (1991) : Evaluation of the ability of the angiotensinconverting enzyme inhibitor captopril to scavenge reactive oxygen species. Chem Biol Interact; 77:303-314.

34- Sies H. (1993) : Strategies of antioxidant defense. Eur $\mathrm{J}$ Biochem; 215:213- 219.

35- Panda S, Jena SK, Rachita Nanda R, Mangaraj M, and Nayak P. (2016) : Ischaemic Markers in Acute Hepatic Injury. J Clin Diagn Res.; 10(4): BC17-BC20.

36- Wolf PL. (1999) : Biochemical diagnosis of liver disease. Indian Journal of Clinical Biochemistry. Jan 1;14 (1):59-90.

37- Edoardo G. (2005) : Giannini, Roberto Testa, and Vincenzo Savarino Liver enzyme alteration: a guide for clinicians. CMAJ. Feb 1; 172 (3): 367-379.

38- Sergey I. Dikalov and Rafal R. (2013) : Nazarewicz. Angiotensin II-Induced Production of Mitochondrial Reactive Oxygen Species: Potential Mechanisms and Relevance for Cardiovascular Disease. Antioxid Redox Signal.; 19(10): 10851094.

39- Datta G, Fuller BJ, and Davidson BR. (2013) : Molecular mechanisms of liver ischemia reperfusion injury: Insights from transgenic 
Sameh Ahmad Muhammad Abdel-ghany et al ....

knockout models. World J

Gastroenterol.; $19(11)$ :

1683-1698.

40- Kalogeris T, Baines CP, Krenz $M$, and Korthuis RJ. (2012) : Cell Biology of Ischemia/Reperfusion Injury. Int Rev Cell Mol Biol. 298: 229-317.

41- Schindler R., Dinarello C.A. and Koch K.-M. (1995) : Angiotensin - convertingenzyme inhibitors supress synthesis of tumour necrosis factor and interleukin 1 by human peripheral blood mononuclear cells. Cytokine; 7, 526.

42- Peeters AC, Netea MG, Kullberg BJ, Thien $\mathrm{T}$, van der Meer JW. (1998) : The effect of renin-angiotensin system inhibitors on proand anti-inflammatory cytokine production. Immunology. Jul; 94(3):376-9.

43- Tornatore L, Thotakura AK, Bennett J, Moretti M, and Franzoso G. (2012) : The nuclear factor kappa B sig- naling pathway: integrating metabolism with inflammation. Trends in Cell Biology.; 22(11): 557-566.

44- Yoshidome H, Kato A, Edwards MJ, Lentsch AB. (1999) : Interleukin-10 suppresses hepatic ischemia/ reperfusion injury in mice: implications of a central role for nuclear factor kappaB. Hepatology; 30: 2038.

45- Tian $Y$, Jochum W, Georgiev P, Moritz W, Graf R, Clavien PA. (2006) : Kupffer cell-dependent TNF-alpha signaling mediates injury in the arterialized small-forsize liver transplantation in the mouse. Proc Natl Acad Sci USA.; 103: 45984603.

46- Lawrence T. (2009) : The Nuclear Factor NF-kB Pathway in Inflammation. Cold Spring Harb Perspect Biol.; 1(6): a001651.

47- Xu J, Yang Z, Zeng J. (2003) : Role of NF-kappa B in liver MANSOURA MEDICAL JOURNAL 
190 POTENTIAL EFFECT OF CAPTOPRIL, VALSARTAN etc..

ischemia reperfusion injury of rats. J Huazhong Univ Sci Technolog Med Sci; 23: $158-60$.

48- Funaki H, Shimizu K, Harada S, Tsuyama H, Fushida S, Tani T, Miwa K. (2002) : Essential role for nuclear factor kappaB in ischemic preconditioning for ische- mia-reperfusion injury of the mouse liver. Transplantation.; 74: 551-6.

49- Bowie A, O'Neill LA. (2000) : Oxidative stress and nuclear factor-kappaB activation: a reassessment of the evidence in the light of recent discoveries. Biochem Pharmacol; 59: 
الملحخص العربى

\section{التأثير المحتمل للكابتوبريل والفالسارتان و النيموديبين على العامل النووى كابا بي و الدهون المتأكسلدة فى حالة الإصابة الناتجلة عن نقص التروية المتبوع بإعادة ضخ الدم فى كبد الفئران

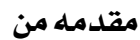

سامح أحمد محمد عبدالغنى مدرس مساعد الفارماكولوجيا الاكلينيكية كلية الطب -جامعة المنصوره هالة عبد الملك العشرى استاذ الفارماكولوجيا الاكلينيكية كلية الطب -جامعة المنصوره مها محمد أمين استاذ الباثولوجي كلية الطب -جامعة المنصوره كروان محمد عبد الرحمن استاذ الفارماكولوجيا الاكلينيكية كلية الطب -جامعة المنصوره عبد الرحمن عبد الفتاح ياسين استاذ الفارماكولوجيا الاكلينيكية كلية الطب -جامعة المنصوره

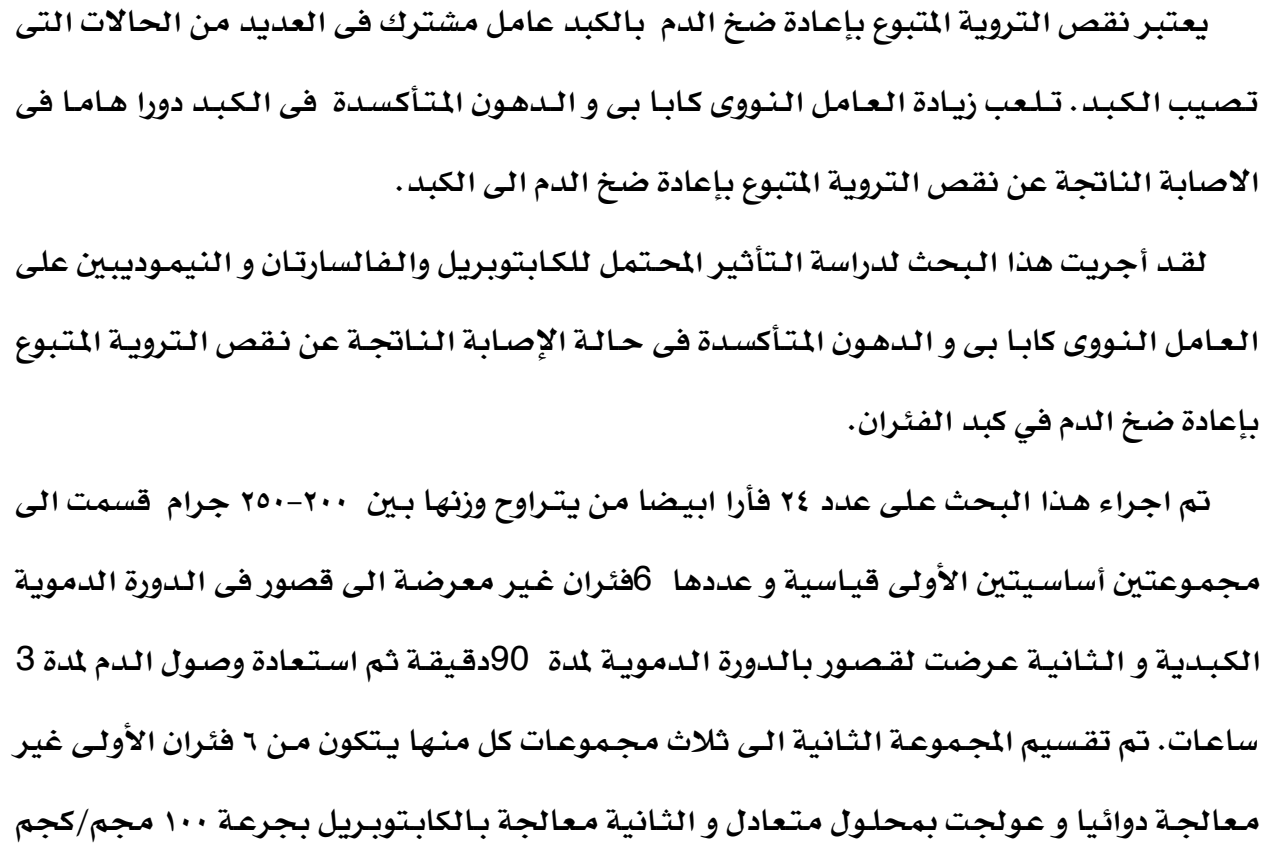

MANSOURA MEDICAL JOURNAL 
يـوميا لمدة V أيـام قبل اجراء الجراحسة و الثالثة معالجـة بالفالسـارتان بجرعة 10 مجم/كجمم يوميا لمدة V أيام قبل اجراء الجراحة

أحدث نقص الترويـة بالكبد فى الفئـران المخدرة بغلق الحزمـة الوعائية الدمويـة الداخلـة للكبد

لمدة ، دقيقة متبوعة بفترة r سـاعات استعادة للدورة الدموية و ذلك برفع الغلق عن الحزمـة. وقد تم تقـييهم مـدى اصـابـة الكبـد بـقياس معـدل انزيم الألانـين ترانزامـينازو انزيهم أسبـارتات ترانزامينازو قياس معدل كلا من معامل تحليل الأورام الفا و انترلوكين ا- بيتـا فى الدم و كذلك قياس نسبة انزيه سـوبر اوكسيد ديسميتوازو نسبة المالونديايهيد فى النسيج الكبدى بالإضافة إلى مـحـتوى تـراكم العـامل النـووى كابـا بى فى النسـيـج الكبـلدى و قــ تم دراسـة التـغـيـرات الشـكليـة والتركيبية في الكبد وتحديد التهاب النسيج الليفى باستخدام صبغة الهيماتوكسلين والايوسين.

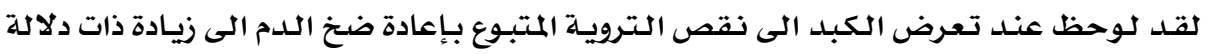
احصـائيـة فى انزيهـات الكبـد و ايضـا زيـادة فى تحليل الأورام الفـا فى الدم و انتـرلوكين ا- بيتا و كذلك زيادة فى نسبـة المالونديـايهيد مـع نقص انزيهم سوبر اوكسيد ديسميتواز فى النسيج الكبدى بالاضـافة الى زيادة مـعدل تراكم العـامل النووى كابا بـ داخل انسـة الكبـد و تـدهور فى تركيب الكبد و التهابات فى النسيج الليفى، فى الجانب الأخر عندما أعطى دواء الكابتوبريل و كذلك دواء الفالسارتان V أيام قبل تعرضها لعملية نقص التروية المتبوع بإعادة ضخ الدم ان مستويات انزيمات الكبد ,تحليل الأورام الفا نتـركوكين ا- بيتا فى الدم و مستوى المالونديايهيد و مسعدل تراكم

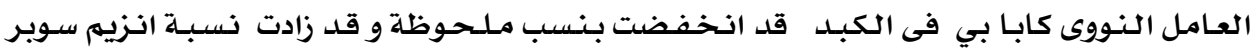

$$
\text { اوكسيد ديسميتواز مـع تحسن الشكل النسيجى للكبد . }
$$

وعلى ضـوء هـذه الدراسـة يمكـن استـنتـاج و اسـتخلاص ان دواء الكـابتوبريل و دواء الفـالسـارتان لهما تأثير وقائى من الاصابة التى تحلدث فى الكبد نتيـجة لنقص التـرويـة المتبوع بإعادة ضـخ الدم و يمكن التوصية باستخدامهما. 